\title{
Light environment affects the levels of resistance hormones in Syngonium podophyllum leaves and its attack by herbivores and fungi
}

c. creative

Botanical Sciences

95 (3): 363-373, 2017

DOI: $10.17129 /$ botsci.1213

Copyright: (C) 2017 García-Guzmán et al. This is an open access article distributed under the terms of the Creative Commons Attribution $\mathrm{Li}$ cense, which permits unrestricted use, distribution, and reproduction in any medium, provided the original author and source are credited.

\section{Author contributions}

Graciela García-Guzmán: conceived the idea, analysed data and wrote the paper. Frida Domínguez-Velázquez: analysed data, and performed the methodology.

Jaime Mendiola-Soto: analysed data, and performed the methodology.

Martin Heil: conceived the idea, analysed data and wrote the paper.

${ }^{1}$ Instituto de Ecología, Universidad Nacional Autónoma de México, México

${ }^{2}$ Departamento de Ingeniería Genética, Centro de Investigación y de Estudios Avanzados, Irapuato, Guanajuato, México

* Corresponding author: mheil@ira.cinvestav.mx
Graciela García-Guzmán ${ }^{1}$ Frida Domínguez-Velázquez ${ }^{1}$, Jaime MendiolaSOTO² AND Martin Hell ${ }^{2 *}$

\section{Abstract}

Background: Little is known on factors determining infection of tropical plants by fungal pathogens, although multiple studies on model species show that light conditions affect the two major hormones that control resistance in plants to enemies. This is the first study using a natural population of a wild tropical plant to relate light conditions to resistance hormones and, the beneficial and detrimental interactions with insects and fungi.

Hypothesis: Light conditions affect the endogenous levels of resistance hormones and thereby cause quantitative shifts among herbivores and nectrotrophic, biotrophic and endophytic fungi.

Studied species: The tropical vine Syngonium podophyllum.

Study site: Los Tuxtlas tropical rain forest, Mexico.

Methods: We used GC-MS to quantify the concentration of the two resistance hormones in intact leaves and natural levels of herbivory and fungal disease in S. podophyllum plants growing naturally in the full sun or in the shade.

Results: The proportion of leaves damaged by herbivores or infected by hemibiotrophic or necrotrophic pathogens was higher in shade than under full-light conditions. Damage caused by biotrophic pathogens was frequently observed in sun but not in shade. Levels of both hormones in phenotypically healthy leaves were higher in sun than in shade.

Conclusions: (i) light has an effect on concentrations of plant resistance hormones in nature; (ii) these differences have consequences for fungi and animals that naturally interact with the plant, and (iii) the described effect can represent a physiological mechanism via which an abiotic factor affects the members of the guilds at higher trophic levels.

Key Words: biotroph, fungal pathogen, endophyte, herbivore, hormone crosstalk, ITS5, jasmonic acid, necrotroph, resistance, salicylic acid

\section{Resumen}

Antecedentes: Poco se sabe sobre los factores que determinan la infección de plantas tropicales por patógenos, pero varios estudios con especies modelo muestran que las condiciones lumínicas afectan a las hormonas que controlan la resistencia de las plantas contra sus enemigos. Este es el primer estudio que analiza como las condiciones lumínicas afectan a las hormonas de resistencia y sus interacciones con insectos y hongos en una población silvestre.

Hipótesis: Las condiciones lumínicas afectan los niveles endógenos de las hormonas de resistencia y por lo tanto afectan la incidencia de herbívoros y patógenos necrótrofos, biótrofos y endófitos.

Especie estudiada: Syngonium podophyllum.

Sitio de estudio: Los Tuxtlas, Veracruz, México.

Métodos: Se utilizó GC-MS para cuantificar la concentración de hormonas de resistencia en hojas sanas y se evaluaron los niveles de daño por herbívoros y hongos patógenos en plantas de sol y sombra.

Resultados: La proporción de hojas dañadas por herbívoros o infectadas por patógenos hemibiótrofos o necrótrofos fue mayor en la sombra que en luz. El daño causado por patógenos biótrofos se detectó en sol pero no en sombra. Los niveles de las hormonas de resistencia fueron más altos en sol que en sombra.

Conclusiones: (i) la luz afecta la concentración de las hormonas de resistencia en plantas; (ii) estas diferencias afectan a los hongos y animales que interactúan naturalmente con la planta, y (iii) estos efectos pueden representar un mecanismo fisiológico a través del cual un factor abiótico afecta a los miembros de los gremios a niveles tróficos superiores.

Palabras claves: ácido jasmónico, ácido salicílico, biótrofo, crosstalk, endófito, herbívoro, hongo patógeno, ITS5, necrótrofo, resistencia 
lants in natural as well as agro-ecosystems are continuously under attack by their biological enemies: herbivores and microbial pathogens. However, the ecological research into plant-enemy interactions in natural ecosystems is dominated by studies on insect herbivores, whereas plant pathology is dominated by studies on crops and a few model plants, like Arabidopsis thaliana (cf. Figure 3 in García-Guzmán \& Heil 2014). The aim of the present study was to provide a first dataset that relates light conditions to the frequency at which a tropical plant is attacked by herbivores or biotrophic vs. necrotrophic fungal pathogens, or colonized by symptomless endophytic fungi, and to propose the control of plant-enemy interactions by plant hormone signalling as a putative physiological explanation of effects of ambient light on the frequencies of herbivores and pathogens of tropical plants. Resistance in plants to insects and microbial enemies is commonly controlled by two hormones: jasmonic acid (JA) controls the resistance to herbivores and necrotrophs, and is consequently induced after the respective attacks, whereas salicylic acid (SA) controls the infection by biotrophic pathogens (Thaler et al. 2012). Besides pathogens, plants are also colonized by fungal endophytes, which grow in the intercellular spaces without causing symptoms of disease. Phylogenetic analyses indicate that endophytes are genetically more closely related to necrotrophs, rather than biotrophs (Delaye et al. 2013), but it remains unknown how the host ranges of endophytes are determined and how endophytes are kept in the non-symptomatic stage.

Interestingly, changing light conditions can cause a symptomless endophyte to shift to necrotrophy (Álvarez-Loayza et al. 2011). Light conditions interact in multiple ways with plant resistance (Ballaré et al. 2012). Among others, low red:far-red ratios as they occur in the forest understory can inhibit JA signalling (Ballaré et al. 2012), but we do not know to which degree such physiological events determine the more general patterns in the attack of tropical wild plants by enemies with different life histories. A literature survey revealed more reports for biotrophic fungal pathogens on light-demanding herbaceous tropical plants, whereas necrotrophic fungal pathogens more frequently attack shade-tolerant host species (García-Guzmán \& Heil 2014). However, the possible explanations for this general pattern comprised both taxonomic (i.e., genetic) and environmental factors. With the present study we aim to provide a first dataset that allows to test whether the above-mentioned general patterns also apply at the within-species level. Using leaves of plants of a single species, we related light conditions (full sun vs. shade) with the endogenous levels of SA and JA and with the average levels of damage caused by herbivores and biotrophic vs. necrotrophic pathogens as well as the frequency of symptomless endophytes.

\section{Methods and materials}

Study species. Syngonium podophyllum Schott (Araceae) is an evergreen climbing epiphyte found in tropical humid forests and disturbed areas of Mexico, and other countries from Central and South America. The stems are 10 to 20 metres long, and support the plants on tree trunks by means of adventitious roots. The leaves vary greatly as the plant ages. When young they have the shape of an arrowhead, but as they mature this changes and lobes develop at the base of the leaves. The older the plant is, the more lobes the full-sized leaves will have (Morgan et al. 2004). Syngonium podophyllum grows both in the forest understory and in the full sun in the tropical rain forests of Mexico and is frequently affected by foliar fungal pathogens (GarcíaGuzmán \& Dirzo 2001).

Study site. The study was carried out at the tropical rain forest of Los Tuxtlas (Southern Veracruz, Mexico; $95^{\circ} 04^{\prime}$ and $95^{\circ} 09^{\prime} \mathrm{W}, 18^{\circ} 34^{\prime}$ and $18^{\circ} 36^{\prime} \mathrm{N}$; altitude ca. 530m). The mean annual temperature is $24^{\circ} \mathrm{C}$ and the mean annual rainfall is $4,639 \mathrm{~mm}$ (Bongers et al. 1988). Precipitation is seasonal, with a short dry season between March and May (Soto \& Gama 1997). The predominant vegetation in the area is classified as lowland tropical high evergreen rain forest with a canopy height ranging from 30 to $35 \mathrm{~m}$ (Bongers et al. 1988, Ibarra-Manríquez et al. 1997).

Methods. In order to describe the frequency at which fungal pathogens and herbivores affect this species under different light environments, twenty plants were chosen randomly from the 
Figure 1. Syngonium podophyllum leaves affected by necrotrophic A) hemibiotrophic B), and C) biotorphic pathogens.
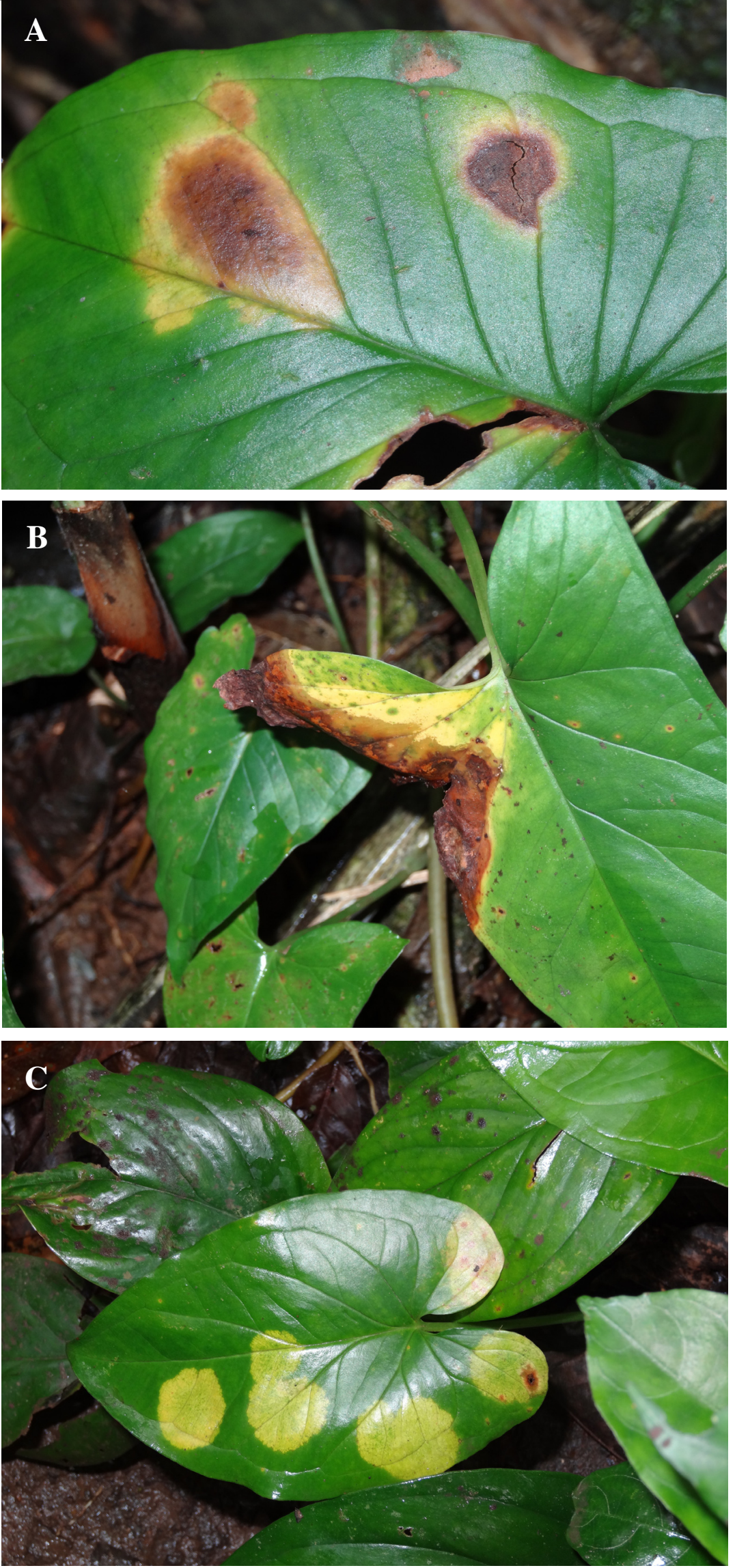
natural population at the study site, with the only restriction that they had two phenotypically undamaged leaves (which were used for the analysis of endogenous JA and SA and for the isolation of fungal endophytes). Half of the plants were growing in the sun $\left(200 \pm 3.94 \mu \mathrm{M} / \mathrm{m}^{2} / \mathrm{s}\right)$ and the other half in the shade $\left(5 \pm 0.58 \mu \mathrm{M} / \mathrm{m}^{2} / \mathrm{s}\right)$. We measured light intensity with a luxometer (Li-COR LI-250, USA).

Two undamaged leaves per plant were selected and cut in half transversally with scissors. One part was shock frozen in liquid nitrogen for the quantification of endogenous levels of defence hormones (Heil et al. 2012) and the remaining part was rinsed with sterile water and cut into at least ten sections (of ca. $3 \mathrm{~mm}^{2}$ ) per leaf. The segments were surface-sterilized by serial immersion in $95 \%$ ethanol (10 s), $0.525 \%$ sodium hypochlorite $(2 \mathrm{~min})$, and $70 \%$ ethanol (2 $\mathrm{min}$ ) and allowed to surface-dry under sterile conditions. Ten segments per leaf were selected haphazardly and plated individually on $1 \mathrm{ml}$ of potato dextrose agar (PDA) in a sterile $2 \mathrm{ml} \mathrm{mi-}$ crocentrifuge tube. The tubes were incubated at room temperature for four months and emerging hyphae were subcultured to $90 \mathrm{~mm}$ Petri dishes containing PDA, to obtain axenic strains.

We randomly collected three further leaves from each plant to determine their phenotypic level of damage by herbivores and fungal pathogens. Fungal pathogens were grouped according to the characteristic symptoms caused: necrotic irregular spots (considered to be caused by necrotrophs), necrotic spots with a chlorotic halo (indicating hemibiotrophic pathogens), and circular chlorotic spots (considered as biotrophic lesions) (cf. Figure 1). Five leaves from each, sun and shade areas showing disease symptoms were used to isolate and identify the causal agents of damage: leaf sections of the affected area including a marginal healthy section of ca. $3 \mathrm{~mm}$ width were disinfected as mentioned above and placed in safe-lock Eppendorf tubes containing PDA to be further treated as described above.

For the preliminary, sequence-based characterisation of common fungal strains, total genomic DNA was extracted from each isolate and the nuclear ribosomal internal transcribed spacers, the 5.8S gene (ITSrDNA) and ca. 600 bp of the ribosomal large subunit (LSUrDNA) were amplified as a single fragment, using primers ITS5 (GGAAGTAAAAGTCGTAACAAGG) and LR3 (CCGTGTTTCAAGACGGG ; see http://biology.duke.edu/fungi/mycolab/primers.htm). All products yielding single bands were purified, normalized, and sequenced on an ABI 3730-xl DNA Analyser (Applied Biosystems; www.appliedbiosystems.com). Annotation used the top hit in a GenBank BLAST sequence similarity search at NCBI, and UNITE (http://unite.ut.ee/index.php).

\section{Results}

The endogenous levels of resistance hormones in phenotypically healthy leaves were significantly correlated with light conditions: leaves of shaded plants contained significantly lower concentrations of both SA and JA than leaves from plants in full sun areas (for SA: t-test: $p=$ $0.011, \mathrm{n}=10$; for JA: t-test: $p<0.001, \mathrm{n}=10$; see Figure 2A). Concordantly, the proportion of leaves free of symptoms of fungal infection was lower in the forest understory than in full sun areas, whereas the proportion of leaves damaged by herbivores was significantly higher in

Table 1. Identity of fungi isolated from Syngonium podophyllum leaves, including environment from where they were isolated, expressed fungal life style, and GenBank and Unite accession numbers.

\begin{tabular}{llllll} 
Isolate Code & BLAST NCBI & Unite Accession & GenBank Accession & Environment & Fungal life style \\
\hline FD4 & Hymenochaete sp. & UDB016365 & JQ780066.1 & Shade & Endophyte \\
FD6 & Xylaria sp. & UDB015373 & JX427059.1 & Full sun & Hemibiotrophic pathogen \\
FD8 & Phlebiopsissp. & EU118662 & JX946673.1 & Full sun & Necrotic pathogen \\
FD9 & Bjerkandera sp. & UDB017981 & KJ140583.1 & Full sun & Endophyte \\
FD10 & Aspergillus sp. & EF661220 & KF938958.1 & Shade & Endophyte \\
FD11 & Hyphodermella sp. & EU118630 & KF638510.1 & Shade & Endophyte \\
FD12 & Aspergillus sp. & EF661220 & KF619560.1 & Shade & Endophyte \\
FD17 & Penicillium sp. & JF922035 & KF880953.1 & Shade & Endophyte \\
FD21 & Penicillium sp. & AF034450 & KF880953.1 & Shade & Endophyte \\
FD23 & Penicillium chrysogenum & AF034450 & KF938433.1 & Full sun & Endophyte \\
\hline
\end{tabular}


SA

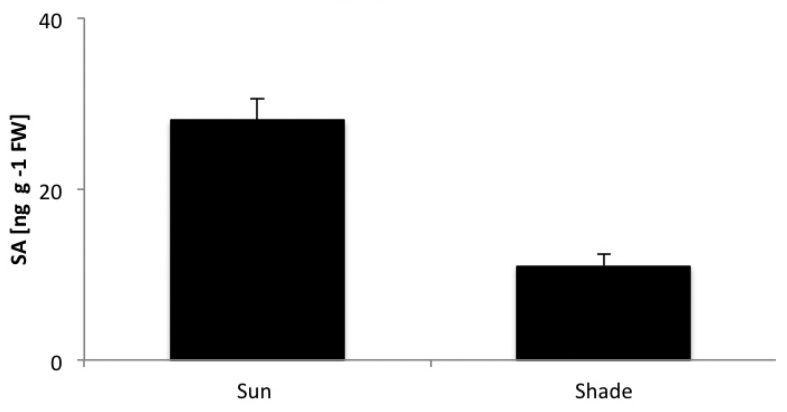

Sun
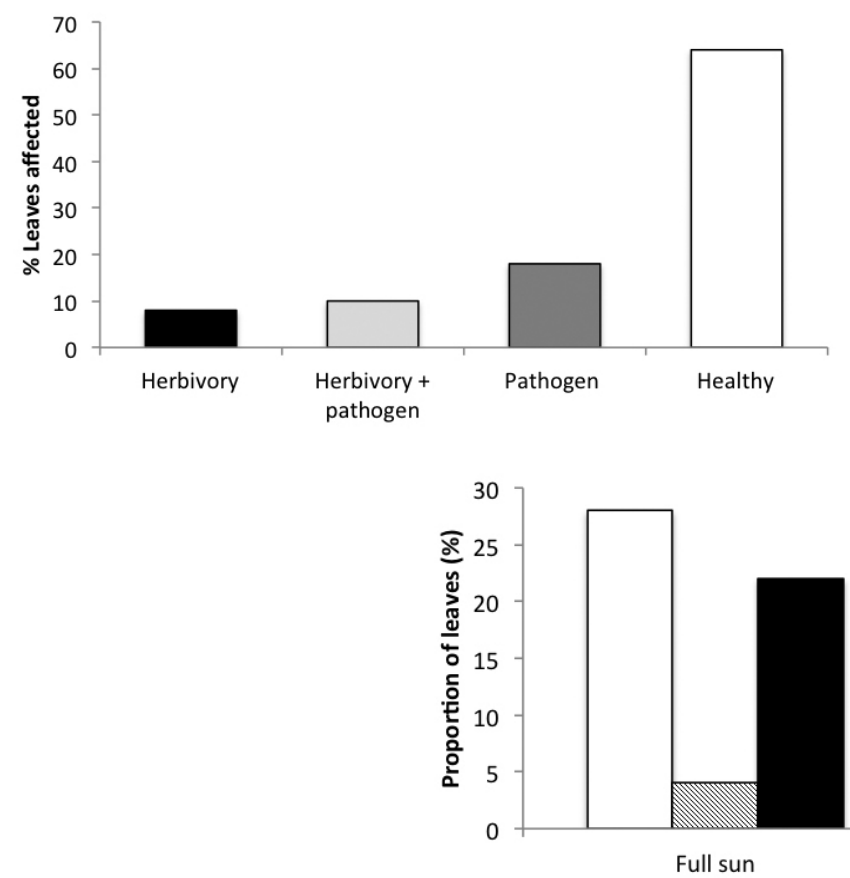

$\square$ Biotrophic pathogens
JA

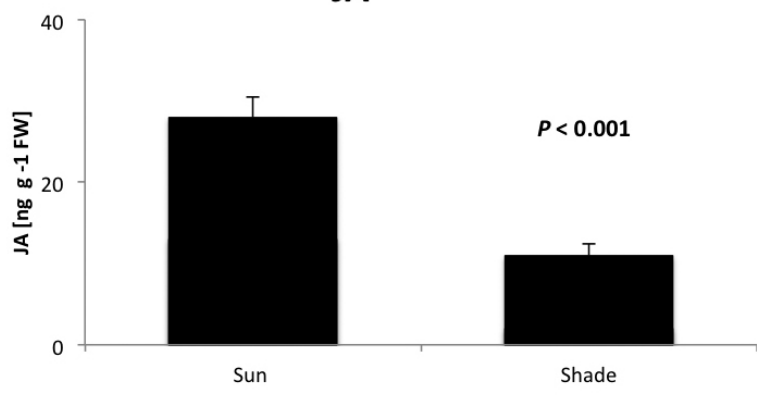

Shade

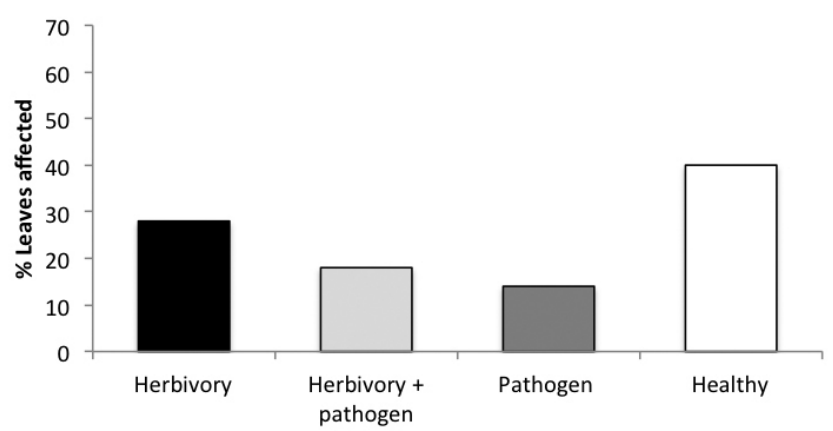

Necrotrophic pathogens

Figure 2. Light dependency of endogenous levels of defence hormones and damage caused by biological enemies with different life histories in wild Syngonium podophyllum. Panel A depicts the endogenous concentrations [in ng per gram leaf fresh mass] of salicylic acid (SA) and jasmonic acid (JA) in phenotypically healthy leaves $(n=10$ samples from different individual plants per condition). Panel B indicates the percentages of leaves affected only by herbivores, by both herbivores and fungal pathogens, only by fungal pathogens, or that were phenotypically healthy. Panel $\mathbf{C}$ depicts the percentage of leaves affected by biotrophic pathogens (live in and consume living plant tissue), necrotrophic pathogens (kill host tissue and consume the dead cells) or hemibiotrophic pathogens (start as biotrophs and the shift to a necrotrophic lifestyle).

shaded than in full sun areas $\left(\chi^{2}=5.56\right.$; $\mathrm{df}=1 ; p<0.05$; see Figure 2B). Separating for different types of fungal pathogens, we found that $28 \%$ of the leaves in the sun were affected by biotrophic pathogens, which were not detected in shaded leaves $\left(\chi^{2}=15.23 ; \mathrm{df}=2 ; p<0.01\right.$; Figure $2 \mathrm{C}$ ). By contrast, relatively more leaves in the shade were damaged by necrotrophic and hemibiotrophic pathogens.

We could cultivate - and preliminarily annotate - 25 fungal strains, nine of which were isolated from plants growing in full sun areas and 16 from plants in the forest understory (Table 1, Appendix 1 and 2). Endophytes comprised a much higher diversity than pathogens among these cultivable strains. Eight strains cultured from leaves in the sun were symptomless endophytes and 
one strain was likely to be a hemibiotrophic pathogen. Among the fungi isolated from shade, $87.5 \%$ corresponded to asymptomatic endophytic fungi and $12.5 \%$ were from necrotrophic lesions. The strains from necrotrophic lesions in most cases had the same phenotype when they were cultivated on PDA agar and even those two strains that appeared to be morphologically distinct were annotated as the same species, Phlebiopsis flavidoalba (Appendixes 1 and 2). By contrast, we could cultivate 14 morphologically distinct endophytic strains from symptomless leaves in the shade, which were annotated as nine different species (Table 1, Appendixes 1 and 2)

\section{Discussion}

Light conditions significantly affected the levels of defence-related hormones in undamaged leaves of Syngonium podophyllum and the frequency of attack by insect herbivores or necrotrophic vs. biotrophic fungal pathogens. The concentration of both JA and SA was higher in plants grown in the sun than in the shade, probably due to the infection of sun plants with biotrophic and/or hemibiotrophic pathogens that were yet in an asymptomatic stage when leaves were collected, but nevertheless causing an induction of plant defences. Concordantly, herbivores and necrotrophic fungal pathogens damaged more leaves in the shade. As we measured defensive hormones in phenotypically undamaged leaves, we conclude that plants in the understory of a tropical rainforest might be limited in their capacity to express hormone-based defences.

Our data stem from one collection event at one site and, thus, provide only correlative evidence for interactions among abiotic factors, plant defence hormones and the relative abundances of different types of attackers. In particular, different levels in standing damage can result from varying plant resistance levels or, rather, from different degrees of enemy pressure. Nevertheless, the quantitative patterns that we observed here for a single plant species resembled patterns in the numbers of reports on fungal pathogens on light demanding vs. shade-tolerant hosts (García-Guzmán \& Heil 2014), which makes it tempting to speculate that the general patterns are mainly determined by environmental factors, rather than the genotypes of the hosts.

Our study opens several new questions concerning the ontogeny of plant defences and on the mechanism via which light affects plant defence signalling and, consequently, the life histories of other species. First, Syngonium podophyllum starts its life cycle in the shaded understory, which could make the early stage more vulnerable to attack by pathogens and herbivores. Because this study only used adult plants, it remains to be investigated whether the early stages possess any alterative, i.e., hormone-independent defence strategies.

Second, more endophytes were isolated from plants in the shade, which underlines the general similarity among endophytes and necrotrophic fungal pathogens rather than the biotrophic pathogens (Delaye et al.2013). However, strains isolated from necrotic tissue in the shade and from symptomless tissue in the sun were likewise were annotated as Phlebiopsis flavidoalba based on their ITS sequence, and strains isolated from a dark brown leaf spot surrounded by a chlorotic halo (which indicates a hemibiotroph) in the sun and from symptomless tissues from both shade and sun were equally annotated as Xylaria longipes. Thus, as described earlier (Álvarez-Loayza et al. 2011), light conditions can determine whether a fungus acts as symptomless endophyte or as pathogen.

Reduced JA levels under shade conditions had been predicted earlier and were suggested to be a consequence of the far-red mediated inhibition of JA-signalling in the understory (GarcíaGuzmán \& Heil 2014). This reduction in the resting level in JA might explain the higher levels of herbivore attack and of infection by necrotrophic pathogens in the leaves of shaded plants. Along the same line, plant exposure to UV-B radiation typically increases resistance to herbivores and pathogens (Ballaré et al. 2012). For example, specific leaf mass, which is a correlate of leaf toughness, increased with light intensity in S.podophyllum (Ackerly 1992). Additionally, directly damage caused by high irradiation on at least some of the enemies of the plant could contribute to the lower levels of herbivory and fungal infection in the full sun. Furthermore, biotrophs frequently depend on hexoses during the infection process (Solomon et al.2003) whereas necrotrophs can hydrolyse cell walls, a pattern that makes it tempting to speculate that current photosynthetic rates might be more important for biotrophs than necrotrophs. For endophytes, colonization rates study were positively affected by air humidity in the understory (Arnold \& 
Herre 2003), which might explain the higher colonization rates in shaded plants $v s$. plants in the full sun.

In summary, future research will have to disentangle all the causal relationships that determine the effects of light on plant defence signalling and, consequently, on plant-dependent herbivores and fungi. However, we are confident to conclude that the rate at which biotrophic vs. necrotrophic tropical fungal pathogens attack their hosts depends on the local light conditions and that the capacity of plants to maintain high levels of defence hormones might be impaired in the shaded understory of a topical rainforest

Our results suggest that we should consider light conditions when investigating patterns in the biotic stress of a plant, and that endogenous levels of SA and JA in wild plants are likely to determine the different types of attacker that affect the plants under varying light conditions.

\section{Conclusions and future perspectives}

Light conditions were significantly correlated with the frequency of attack by herbivores and biotrophic $v s$. necrotrophic fungal pathogens, and also correlated with the average concentrations of the resistance hormones, JA and SA. Thus, our study indicates that we should consider light conditions when investigating patterns in the biotic stress of a plant, likely because they affect the plant enemies both directly and via their effects on plant resistance traits. Understanding the underlying physiological mechanisms will require the repetition of this study at different sites, identification of all fungal pathogens and symptomless endophytes that regularly infect S. podophyllum, and then experiments in which healthy plants under controlled light conditions are challenged with specific pathogens. Such studies would have to be accompanied by screenings using healthy susceptible plants and different culture media exposed to the different environments, to neutrally quantify enemy pressure. Only the combination of both strategies can separate the effects of light on plant hormones and inducible resistance traits from its direct effects on the plant enemies.

\section{Acknowledgements}

We thank Rosa María Ádame-Alvarez, Irma Acosta-Calixto, Blanca Hernández-Bautista, Rigoberto Pérez-Ruiz and Mariana Del Olmo-Ruiz for technical assistance. Thanks are also extended to the director of the "Los Tuxtlas Biological Research Station" Rosamond Coates for logistical support. Fieldwork was supported by a Universidad Nacional Autónoma de México - Programa de Apoyo a Proyectos de Investigación e Innovación Tecnológica (UNAM-PAPIIT IN205012) grant to G. García-Guzmán. We thank Ana Mendoza for providing a UNAM-PAPIIT (IN206515) grant to F. Dominguez-Velazquez for undergraduate studies.

\section{Literature cited}

Ackerly DD. 1992. Light, leaf age, and leaf nitrogen concentration in a tropical vine. Oecologia 89:596600. DOI: $10.1007 / \mathrm{BF} 00317169$

Álvarez-Loayza P, White JF, Jr., Torres MS, Balslev H, Kristiansen T, Svenning J-C, Gil N. 2011. Light converts endosymbiotic fungus to pathogen, influencing seedling survival and niche-space filling of a common tropical tree, Iriartea deltoidea. PLOS ONE 6: e16386 DOI:e1638610.1371/journal. pone. 0016386

Arnold AE, Herre EA. 2003. Canopy cover and leaf age affect colonization by tropical fungal endophytes: Ecological pattern and process in Theobroma cacao (Malvaceae). Mycologia 95: 388-398. DOI:10.2307/3761880

Ballaré CL, Mazza CA, Austin AT, Pierik R. 2012. Canopy light and plant health. Plant Physiology 160: 145-155. DOI:10.1104/pp.112.200733

Delaye L, García-Guzmán G, Heil M. 2013. Endophytes versus biotrophic and necrotrophic pathogens - are fungal lifestyles evolutionarily stable traits? Fungal Diversity 60: 125-135. DOI:10.1007/s13225013-0240-y

García-Guzmán G, Dirzo R. 2001. Patterns of leaf-pathogen infection in the understory of a Mexican rain forest: Incidence, spatiotemporal variation, and mechanisms of infection. American of Journal of Botany 88: 634-645. DOI:10.2307/2657063 
Received:

Jamuary 18th, 2017

Accepted:

February 2nd, 2017
García-Guzmán G, Heil M. 2014. Life histories of hosts and pathogens predict patterns in tropical fungal plant diseases. New Phytologist 201: 1106-1120. DOI:10.1111/nph.12562

Heil M, Ibarra-Laclette E, Adame-Álvarez RM, Martínez O, Ramirez-Chávez E, Molina-Torres J, Herrera-Estrella L. 2012. How plants sense wounds: damaged-self recognition is based on plant-derived elicitors and induces octadecanoid signaling. PLOS ONE 7: e30537. doi:10.1371/journal.pone.003053

Solomon PS, Tan K-C, Olover RP. 2003. The nutrient supply of pathogenic fungi; a fertile field for study. Molecular Plant Pathology 4: 203-210. Thaler JS, Humphrey PT, Whiteman NK (2012) Evolution of jasmonate and salicylate signal crosstalk. Trends Plant Sci 17: 260-270. DOI: 10.1016/ j.tplants.2012.02.010 
Appendix 1. Identity of fungi isolated from Syngonium podophyllum leaves, environment from where they were isolated, expressed fungal life styleand GenBank accession numbers.

\begin{tabular}{|c|c|c|c|c|c|c|c|c|}
\hline $\begin{array}{l}\text { Isolate } \\
\text { Code }\end{array}$ & $\begin{array}{l}\text { Sequence } \\
\text { analysed }\end{array}$ & BLAST NCBI & Order & $\begin{array}{l}\text { Query cover } \\
\text { (Ident) }\end{array}$ & $\begin{array}{l}\text { GenBank } \\
\text { accession }\end{array}$ & SCORE & $\begin{array}{l}\text { Light } \\
\text { Environ- } \\
\text { ment }\end{array}$ & $\begin{array}{l}\text { Expressed } \\
\text { fungal life } \\
\text { style }\end{array}$ \\
\hline \multirow[t]{2}{*}{ FD2 } & ITS5 & $\begin{array}{l}\text { Uncultured fungus clone } \\
\text { L042881-122-061-A11 } \\
\text { internal transcribed spacer } 1\end{array}$ & & 394/395(99\%) & $\mathrm{gb}|\mathrm{GU} 054027.1|$ & 725 bits(392) & Shade & $\begin{array}{l}\text { Necrotrophic } \\
\text { pathogen }\end{array}$ \\
\hline & LR3 & $\begin{array}{l}\text { Phanerochaetaceae sp. } \\
\text { ZLY-2010 isolate M19-2 } \\
\text { internal transcribed spacer } 2\end{array}$ & Polyporales & 307/314(98\%) & gb|HM595616.1| & 542 bits(293) & Shade & $\begin{array}{l}\text { Necrotrophic } \\
\text { pathogen }\end{array}$ \\
\hline \multirow[t]{2}{*}{ FD3 } & ITS5 & $\begin{array}{l}\text { Uncultured fungus clone } \\
\text { L042881-122-061-A11 } \\
\text { internal transcribed spacer } 1\end{array}$ & & 402/425(95\%) & gb|GU054027.1| & 649 bits(351) & Shade & $\begin{array}{l}\text { Necrotrophic } \\
\text { pathogen }\end{array}$ \\
\hline & LR3 & $\begin{array}{l}\text { Phanerochaetaceae sp. } \\
\text { ZLY-2010 isolate M19-2 } \\
\text { internal transcribed spacer } 2\end{array}$ & Polyporales & 489/502(97\%) & gb|HM595616.1| & 856 bits(463) & Shade & $\begin{array}{l}\text { Necrotrophic } \\
\text { pathogen }\end{array}$ \\
\hline \multirow[t]{2}{*}{ FD4 } & ITS5 & $\begin{array}{l}\text { Hymenochaete ustulata } \\
\text { voucher He104 internal } \\
\text { transcribed spacer } 1\end{array}$ & Hymenochaetales & 233/249(94\%) & gb|JQ780066.1| & 366 bits(198) & Shade & Endophyte \\
\hline & LR3 & $\begin{array}{l}\text { Hymenochaete resupinata } \\
\text { partial } 28 \mathrm{~S} \text { rRNA gene }\end{array}$ & Hymenochaetales & 254/259(98\%) & emb|HE650988.1| & | 449 bits(243) & Shade & Endophyte \\
\hline \multirow[t]{2}{*}{ FD6 } & ITS5 & $\begin{array}{l}\text { Xylaria hypoxylon isolate } \\
\text { SACCR } 010851 \text { internal } \\
\text { transcribed spacer } 1\end{array}$ & Xylariales & $428 / 428(100 \%)$ & gb|JX427059.1| & 791 bits(428) & Full sun & $\begin{array}{l}\text { Hemibiotrophic } \\
\text { pathogen }\end{array}$ \\
\hline & LR3 & $\begin{array}{l}\text { Xylaria sp. DIS 258g } 28 S \\
\text { ribosomal RNA gene, } \\
\text { partial sequence }\end{array}$ & Xylariales & $312 / 312(100 \%)$ & gb|DQ327629.1| & 577 bits(312) & Full sun & $\begin{array}{l}\text { Hemibiotrophic } \\
\text { pathogen }\end{array}$ \\
\hline \multirow[t]{2}{*}{ FD7 } & ITS5 & $\begin{array}{l}\text { Favodon flavus strain } \\
\text { xsd08084 18S ribosomal } \\
\text { RNA gene }\end{array}$ & Polyporales & $402 / 402(100 \%)$ & gb|FJ478126.1| & 743 bits(402) & Shade & Endophyte \\
\hline & LR3 & $\begin{array}{l}\text { Phanerochaete sp. } 2 \\
\text { KUC8361 28S ribosomal } \\
\text { RNA gene, partial sequence }\end{array}$ & Corticiales & $360 / 360(100 \%)$ & gb|FJ471549.1| & 665 bits(360) & Shade & Endophyte \\
\hline \multirow[t]{2}{*}{ FD8 } & ITS5 & $\begin{array}{l}\text { Phlebiopsis gigantea isolate } \\
\text { ZS2 } 18 \text { S ribosomal RNA gen }\end{array}$ & Polyporales & 287/301(95\%) & gb|JX946673.1| & 472 bits(255) & Full sun & $\begin{array}{l}\text { Necrotrophic } \\
\text { pathogen }\end{array}$ \\
\hline & LR3 & $\begin{array}{l}\text { Phlebiopsis flavidoalba } \\
\text { voucher KHL } 13055 \text { (GB) } \\
18 \text { ribosomal RNA gene }\end{array}$ & Polyporales & 285/289(99\%) & gb|EU118662.1| & 512 bits(277) & Full sun & $\begin{array}{l}\text { Necrotrophic } \\
\text { pathogen }\end{array}$ \\
\hline \multirow[t]{2}{*}{ FD9 } & ITS5 & $\begin{array}{l}\text { Bjerkandera fumosa voucher } \\
\text { CFMR:DLL2011-062 18S } \\
\text { ribosomal RNA gene }\end{array}$ & Polyporales & 398/420(95\%) & gb|KJ140583.1| & 651 bits(352) & Full sun & Endophyte \\
\hline & LR3 & $\begin{array}{l}\text { Bjerkandera adusta isolate } \\
\text { X-75 } 18 \mathrm{~S} \text { ribosomal RNA gene }\end{array}$ & Polyporales & $344 / 349(99 \%)$ & gb|KC176354.1| & 617 bits(334) & Full sun & Endophyte \\
\hline \multirow[t]{2}{*}{ FD10 } & ITS5 & $\begin{array}{l}\text { Aspergillus aculeatus strain } \\
\text { HFpk01 internal transcribed } \\
\text { spacer } 1\end{array}$ & Eurotiales & $328 / 328(100 \%)$ & gb|KF938958.1| & 606 bits(328) & Shade & Endophyte \\
\hline & LR3 & $\begin{array}{l}\text { Aspergillus sp. MMB62 gene } \\
\text { for } 28 \text { S ribosomal RNA, } \\
\text { partial sequence }\end{array}$ & Eurotiales & $301 / 301(100 \%)$ & dbj|AB734808.1| & 556 bits(301) & Shade & Endophyte \\
\hline
\end{tabular}




\begin{tabular}{|c|c|c|c|c|c|c|c|c|}
\hline $\begin{array}{l}\text { Isolate } \\
\text { Code }\end{array}$ & $\begin{array}{l}\text { Sequence } \\
\text { analysed }\end{array}$ & BLAST NCBI & Order & $\begin{array}{l}\text { Query cover } \\
\text { (Ident) }\end{array}$ & $\begin{array}{l}\text { GenBank } \\
\text { accession }\end{array}$ & SCORE & $\begin{array}{l}\text { Light } \\
\text { Environ- } \\
\text { ment }\end{array}$ & $\begin{array}{l}\text { Expressed } \\
\text { fungal life } \\
\text { style }\end{array}$ \\
\hline \multirow[t]{2}{*}{ FD11 } & ITS5 & $\begin{array}{l}\text { Hyphodermella sp. Achao } 41 \\
18 \mathrm{~S} \text { ribosomal RNA gene }\end{array}$ & Polyporales & 267/290(92\%) & gb|KF638510.1| & 396 bits(214) & Shade & Endophyte \\
\hline & LR3 & $\begin{array}{l}\text { Hyphodermella rosae strain } \\
\text { MA-Fungi } 7554128 \mathrm{~S} \\
\text { ribosomal RNA (LSU) gene }\end{array}$ & Polyporales & 183/190(96\%) & gb|JN939595.1| & 313 bits(169) & Shade & Endophyte \\
\hline \multirow[t]{2}{*}{ FD12 } & ITS5 & $\begin{array}{l}\text { Aspergillus aculeatus isolate } \\
18 \mathrm{H} 6 \text { internal transcribed } \\
\text { spacer } 1,\end{array}$ & Eurotiales & $241 / 241(100 \%)$ & gb|KF619560.1| & 446 bits(241) & Shade & Endophyte \\
\hline & LR3 & $\begin{array}{l}\text { Aspergillus sp. MMB62 gene } \\
\text { for } 28 \text { S ribosomal RNA }\end{array}$ & Eurotiales & $205 / 205(100 \%)$ & $\mathrm{dbj}|\mathrm{AB} 734808.1|$ & 379 bits(205) & Shade & Endophyte \\
\hline \multirow[t]{2}{*}{ FD13 } & ITS5 & $\begin{array}{l}\text { Sordariomycetes sp. genotype } \\
415 \text { isolate FL1442 internal } \\
\text { transcribed spacer } 1\end{array}$ & Xylariales & 333/334(99\%) & gb|JQ761052.1| & 612 bits(331) & Full sun & Endophyte \\
\hline & LR3 & $\begin{array}{l}\text { Sordariomycetes sp. genotype } \\
415 \text { isolate FL1106 internal } \\
\text { transcribed spacer } 1\end{array}$ & Xylariales & 272/273(99\%) & gb|JQ760729.1| & 499 bits(270) & Full sun & Endophyte \\
\hline \multirow[t]{2}{*}{ FD14 } & ITS5 & $\begin{array}{l}\text { Tinctoporellus epimiltinus } \\
\text { voucher Dai } 11831 \text { internal } \\
\text { transcribed spacer } 1\end{array}$ & Polyporales & $391 / 391(100 \%)$ & gb|JQ319492.1| & 723 bits(391) & Full sun & Endophyte \\
\hline & LR3 & $\begin{array}{l}\text { Fungal endophyte culture- } \\
\text { collection STRI:ICBG-Panama: } \\
\text { TK375 } 18 \text { S ribosomal RNA gen }\end{array}$ & $\begin{array}{l}\text { Polyporales } \\
\text { ne }\end{array}$ & $327 / 327(100 \%)$ & gb|KF435681.1| & 604 bits(327) & Full sun & Endophyte \\
\hline \multirow[t]{2}{*}{ FD15 } & ITS5 & $\begin{array}{l}\text { Homobasidiomycetes sp. } \\
\text { DIS 181c } 28 \text { S ribosomal } \\
\text { RNA gene, }\end{array}$ & Agaricales & 253/256(99\%) & gb|DQ327647.1| & 457 bits(247) & Full sun & Endophyte \\
\hline & LR3 & $\begin{array}{l}\text { Fungal sp. MS367b internal } \\
\text { transcribed spacer } 1\end{array}$ & & 275/277(99\%) & gb|JQ919943.1| & 501 bits(271) & Full sun & Endophyte \\
\hline \multirow[t]{2}{*}{ FD16 } & ITS5 & $\begin{array}{l}\text { Sordariomycetes sp. genotype } \\
438 \text { isolate FL1396 internal } \\
\text { transcribed spacer } 1 \text {, }\end{array}$ & Xylariales & $252 / 252(100 \%)$ & gb|JQ761013.1| & 466 bits(252) & Shade & Endophyte \\
\hline & LR3 & $\begin{array}{l}\text { Sordariomycetes sp. genotype } \\
314 \text { isolate FL1048 internal } \\
\text { transcribed spacer 1, }\end{array}$ & Xylariales & $230 / 230(100 \%)$ & gb|JQ760671.1| & 425 bits(230) & Shade & Endophyte \\
\hline
\end{tabular}


Appendix 2. Identity of fungi isolated from Syngonium podophyllum leaves using Blast Unite, environment from where they were isolated and expressed life style.

\begin{tabular}{|c|c|c|c|c|c|c|c|c|}
\hline ID & $\begin{array}{l}\text { Accession } \\
\text { number }\end{array}$ & Organism & Score & Expect & Identities & Gaps & $\begin{array}{c}\text { Environ- } \\
\text { ment }\end{array}$ & $\begin{array}{l}\text { Expressed life } \\
\text { style }\end{array}$ \\
\hline FD2 & EU118662 & Phlebiopsis flavidoalba & 1590 & 0 & $94 \%$ & $0 \%$ & Shade & Necrotrophic pathogen \\
\hline FD3 & EU118662 & Phlebiopsis flavidoalba & 1590 & 0 & $94 \%$ & $0 \%$ & Shade & Necrotrophic pathogen \\
\hline FD8 & EU118662 & Phlebiopsis flavidoalba & 1590 & 0 & $94 \%$ & $0 \%$ & Full sun & Endophyte \\
\hline FD7 & EU118654 & Phlebia firma & 761 & 0 & $93 \%$ & $0 \%$ & Shade & Endophyte \\
\hline FD11 & EU118630 & Hyphodermella corrugata & 734 & 0 & $96 \%$ & $0 \%$ & Shade & Endophyte \\
\hline FD9 & UDB017981 & Bjerkandera adusta & 1390 & 0 & $95 \%$ & $1 \%$ & Full sun & Endophyte \\
\hline FD27 & HQ604797 & Phlebia radiata & 1598 & 0 & $93 \%$ & $1 \%$ & Full sun & Endophyte \\
\hline FD20 & JN649346 & Hydnopolyporu imbriatus & 1534 & 0 & $93 \%$ & $1 \%$ & Shade & Endophyte \\
\hline FD14 & KC581319 & Ganoderma applanatum & 1495 & 0 & $94 \%$ & $0 \%$ & Full sun & Endophyte \\
\hline FD24 & KC581319 & Ganoderma applanatum & 1495 & 0 & $94 \%$ & $0 \%$ & Shade & Endophyte \\
\hline FD26 & JN649335 & Cotylidia undulata & 795 & 0 & $91 \%$ & $0 \%$ & Shade & Endophyte \\
\hline FD28 & UDB016320 & Xylodon rimosissimus & 1405 & 0 & $95 \%$ & $0 \%$ & Full sun & Endophyte \\
\hline FD4 & UDB016365 & Hymenochaete acerosa & 856 & 0 & $96 \%$ & $0 \%$ & Shade & Endophyte \\
\hline FD15 & AF539711 & Cortinarius cervinus & 930 & 0 & $95 \%$ & $0 \%$ & Full sun & Endophyte \\
\hline FD12 & EF661220 & Aspergillus aculeatus & 2060 & 0 & $100 \%$ & $0 \%$ & Shade & Hemibiotrophic pathoger \\
\hline FD10 & EF661220 & Aspergillus aculeatus & 2089 & 0 & $100 \%$ & $0 \%$ & Shade & Endophyte \\
\hline FD17 & JF922035 & Penicillium chrysogenum & 1007 & 0 & $100 \%$ & $0 \%$ & Shade & Endophyte \\
\hline FD21 & AF034450 & Penicillium chrysogenum & 1986 & 0 & $100 \%$ & $0 \%$ & Shade & Endophyte \\
\hline FD23 & AF034450 & Penicillium chrysogenum & 988 & 0 & $99 \%$ & $0 \%$ & Full sun & Endophyte \\
\hline FD6 & UDB015373 & Xylaria longipes & 1384 & 0 & $95 \%$ & $1 \%$ & Full sun & Necrotrophic pathogen \\
\hline FD29 & UDB015373 & Xylaria longipes & 1384 & 0 & $95 \%$ & $1 \%$ & Shade & Endophyte \\
\hline FD13 & UDB015373 & Xylaria longipes & 1848 & 0 & $97 \%$ & $0 \%$ & Full sun & Endophyte \\
\hline FD22 & UDB015373 & Xylaria longipes & 1425 & 0 & $94 \%$ & $0 \%$ & Shade & Endophyte \\
\hline FD16 & UDB015373 & Xylaria longipes & 1572 & 0 & $96 \%$ & $0 \%$ & Shade & Endophyte \\
\hline FD19 & UDB013130 & Ramaria sp. & 745 & 0 & $92 \%$ & $0 \%$ & Shade & Endophyte \\
\hline
\end{tabular}

